\title{
Subglacial processes on an Antarctic ice stream bed. 2: Can modelled ice dynamics explain the morphology of mega-scale glacial lineations?
}

\author{
STEWART S.R. JAMIESON, ${ }^{1}$ CHRIS R. STOKES, ${ }^{1}$ STEPHEN J. LIVINGSTONE, ${ }^{2}$ \\ ANDREAS VIELI, ${ }^{3}$ COLM Ó COFAIGH, ${ }^{1}$ CLAUS-DIETER HILLENBRAND ${ }^{4}$ \\ MATTEO SPAGNOLO 5
}

\author{
${ }^{1}$ Department of Geography, Durham University, Durham, UK \\ ${ }^{2}$ Department of Geography, Sheffield University, Sheffield, UK \\ ${ }^{3}$ Department of Geography, University of Zurich, Zurich, Switzerland \\ ${ }^{4}$ British Antarctic Survey, Cambridge, UK \\ ${ }^{5}$ School of Geosciences, University of Aberdeen, Aberdeen, Scotland \\ Correspondence: Stewart S.R. Jamieson <Stewart.Jamieson@durham.ac.uk>
}

\begin{abstract}
Mega-scale glacial lineations (MSGLs) are highly elongate subglacial bedforms associated with ice streaming. However, the link between MSGLs and rapid ice flow is largely qualitative, and there have been few attempts to quantitatively link their formation to ice flow characteristics (e.g. ice velocity, thickness, basal shear stress). We take measurements of MSGLs from a palaeo-ice stream that once occupied Marguerite Trough, Antarctic Peninsula and explore a range of possible correlations with ice dynamics generated from an ensemble of numerical modelling experiments that reproduce the deglaciation of the ice stream. Our results confirm that high mean ice velocities and a weak bed correlate with longer MSGLs. Furthermore, the height of MSGLs are low (2-3 m) where modelled basal shear stress is low, but their height tends to be higher and more variable where basal shear stress is larger. The mean density of MSGLs decreases as ice flux increases. Our analysis further suggests that the length of MSGLs is a function of basal ice velocity and time. Although our data/model correlations confirm the importance of ice velocity in MSGL formation, a significant challenge remains if we are to employ MSGLs as a quantifiable measure of past ice stream velocity.
\end{abstract}

KEYWORDS: bedforms, correlation, glacial lineations, ice stream, ice velocity, numerical model

\section{INTRODUCTION}

Mega-scale glacial lineations (MSGLs) comprise parallel sets of elongate, linear to curvilinear sediment ridges that can be several tens of kilometres long and are typically a few metres high (Clark, 1993; Spagnolo and others, 2014). Their formation is governed by the interaction of ice flowing over a deformable substrate, which is characteristically present beneath ice streams, and MSGLs have been considered to be diagnostic of ice stream flow in numerous palaeo-settings (e.g. Clark, 1993; Stokes and Clark, 1999; Stokes and Clark, 2002; Sejrup and others, 2003; Dowdeswell and others, 2004; Ottesen and others, 2005; Stoker and Bradwell, 2005; Graham and others, 2009; Larter and others, 2009). This assertion has been confirmed by recent geophysical investigations that have demonstrated the presence of MSGLs under a modern ice stream in West Antarctica (King and others, 2009). Despite the association with rapid ice flow, the processes that generate these landforms and the glaciological conditions associated with their formation are poorly understood, with existing theories yet to gain widespread support from large datasets of their morphology (Stokes and others, 2013b; Spagnolo and others, 2014).

Although the formation of MSGLs is poorly constrained, it has been suggested that their elongation/length is a function of ice velocity (Hart, 1999; Stokes and Clark, 2002; Briner, 2007), and that they may be an end-member of a genetic continuum of subglacial bedforms that includes ribbed moraine and drumlins that form under slower ice velocities (Stokes and others, 2013a). However, very few studies have been able to directly and quantitatively compare the morphological characteristics of MSGLs with the properties of ice stream flow (e.g. ice velocity) because of the difficulty in observing landform generation beneath modern ice masses. As a consequence, we have a limited understanding of the glaciological processes and conditions that determine how MSGLs initiate, evolve and elongate.

Several theories of MSGL formation exist (Alley and others, 1986; Boulton, 1987; Engelhardt and others, 1990; Engelhardt and Kamb, 1997; Tulaczyk and others, 2001; Clark and others, 2003; Schoof and Clarke, 2008; Fowler, 2010; Fowler and Chapwanya, 2014) but none are fully supported by analysis of landform sedimentology and morphology (Ó Cofaigh and others, 2013; Stokes and others, 2013b; Spagnolo and others, 2014). This, in conjunction with the lack of physical data confirming past glacier flow conditions, means there is no consensus on the processes of MSGL evolution.

A new approach to understand MSGL formation is to compare observations and measurements of MSGLs against numerical models of ice stream flow in the same setting. In this study, our aim is to compare detailed measurements of landform characteristics from the bed of Marguerite Bay palaeo-ice stream (Fig. 1 of Livingstone and others, this issue) against the properties of the ice stream dynamics 


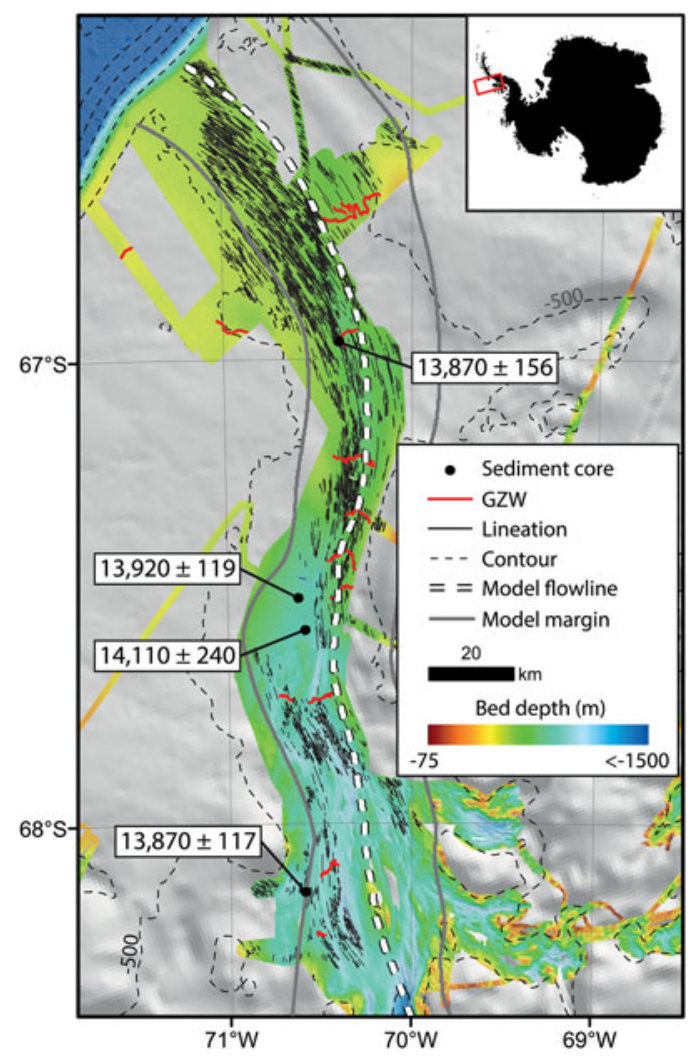

Fig. 1. Map of mega-scale glacial lineations in Marguerite Trough and their position within the ice stream trough and in relation to grounding zone wedges (GZWs). Data Collection Points (DCPs) to which landform statistics are appended are positioned at $1 \mathrm{~km}$ intervals along the model flowline. The inset map shows the location of Marguerite Trough on the western Antarctic Peninsula shelf. Dates are minimum retreat ages initially published by Pope and Anderson (1992); Ó Cofaigh and others (2005); Heroy and Anderson (2007); Kilfeather and others (2011).

(thickness, velocity, etc.) derived from an ensemble of numerical model runs of the ice stream's behaviour. Having done so, we discuss the implications of our results for understanding the processes that control the morphology of MSGLs.

\section{METHODS}

\subsection{Geomorphological record}

A geomorphological map of the Marguerite Bay palaeo-ice stream is published by Livingstone and others (2013), and the bed imprint is described and analysed by Livingstone and others (2016, this issue), which accompanies this paper. The map builds upon a series of marine geophysical surveys and dated sediment cores, which were used to reconstruct the flow and retreat behaviour of the ice stream in detail (Harden and others, 1992; Pope and Anderson, 1992; Ó Cofaigh and others, 2005; Heroy and Anderson, 2007; Anderson and Fretwell, 2008; Kilfeather and others, 2011). By using a $45 \mathrm{~m}$ resolution swath bathymetric DEM of the floor of Marguerite Trough, Livingstone and others, (2013) systematically mapped 5037 MSGLs using ArcGIS (Fig. 1). These were identified as being any glacial lineations on the continuum between 'classical' highly elongated MSGLs and shorter drumlinoid features that is not associated with exposed bedrock, but may or may not have an underlying bedrock control. Using the dataset of lines that represent the crest lines of the MSGLs, we measured their length, density, height and spacing, as well as the thickness of soft till (see Livingstone and others, 2016, this issue) and associated statistics. This resulted in 22 geomorphological variables relating to the shape and distribution of the MSGLs (see Table 1). Any MSGLs that fell outside the geographical extent of the numerical model's lateral margins, as defined by the lateral extent of MSGLs and by the shoulders of the overdeepened floor of Marguerite Trough (Fig. 1; Jamieson and others, 2012; Jamieson and others, 2014) were ignored during this process. In order to compare the two-dimensional (2-D) distribution of MSGLs against the 1-D model, the geomorphological parameters were extrapolated from across-trough measurements and onto a central flowline position, thus compressing them into 1-D form. This was achieved using a series of 'data collection points' (DCPs) located at $1 \mathrm{~km}$ intervals along the centreline of the modelled flowline as points of direct data/model comparison. We acknowledge that this results in loss of detail concerning the lateral distribution of MSGLs, but since the model cannot show laterally variable characteristics due to its 1-D nature, we accept this caveat and only interpret the results in this context. Length, density and soft till thickness of all MSGLs fitting within the margins of the model were calculated as outlined below, and their values then averaged across the width of the ice stream and appended to the nearest DCP (Fig. 2). Mean, maximum, minimum and standard deviations (SDs) were calculated for all the attributes being assigned to a particular DCP (Fig. 2).

Lineation length is measured along the long-axis of each MSGL. MSGL density was calculated in units of length per unit area $\left(\mathrm{m} \mathrm{km}^{-2}\right)$ by summing the length of MSGL sections that fall within a $5 \mathrm{~km}$ search radius of each bathymetry DEM cell and then dividing it by the area of that circle. This generated a continuous surface representing density whose statistics were then appended to the nearest DCP (Fig. 2). This method is a more appropriate way of accounting for the length of MSGLs rather than treating MSGLs in terms of only their mid-points (Livingstone and others, this issue).

Following Spagnolo and others (2014), the spacing of MSGLs was calculated by measuring the separation between digitised MSGL crest lines along a transect aligned perpendicular to ice stream flow and spaced at $1 \mathrm{~km}$ intervals that intersect each DCP (Fig. 2). Where MSGLs were separated by areas of bedrock and could not be formed, the area was treated as 'no-data'. MSGL height statistics were calculated using the difference between the elevation of the ridge crest elevation and the minimum elevation of the inter-MSGL grooves on both sides of the crestline (Fig. 2).

Soft till thicknesses were calculated where acoustic subbottom profiler data permitted (Livingstone and others, this issue). Along each profile, the thickness of soft till was measured at $1 \mathrm{~km}$ intervals. This thickness was determined by measuring the two-way-travel time difference between the seafloor reflector or, if present, the reflector at the base of a postglacial sediment drape, and an underlying prominent acoustic sub-bottom reflector, which corresponds to the surface of an over consolidated stiff till as sediment cores have revealed (Ó Cofaigh and others, 2005). The time difference was converted into thickness (m) using an acoustic velocity of $1500 \mathrm{~m} \mathrm{~s}^{-1}$ (Dowdeswell and others, 2004). 
Table 1. Measured geomorphological characteristics and modelled glaciological characteristics extracted for comparisons

\begin{tabular}{ll}
\hline Measured landform parameter & Modelled glaciological parameter \\
\hline Minimum lineation length & Last ice velocity \\
Maximum lineation length & Maximum ice velocity \\
Mean lineation length & Mean ice velocity \\
SD of length (gives us an idea of heterogeneity) & Cumulative ice velocity \\
Minimum density (cumulative length per $5 \mathrm{~km}$ ) & Last basal shear stress \\
Maximum density (cumulative length per $5 \mathrm{~km}$ ) & Mean basal shear stress \\
Mean density (cumulative length per $5 \mathrm{~km}$ ) & Maximum basal shear stress \\
SD of density (cumulative length per $5 \mathrm{~km}$ ) & Cumulative basal shear stress \\
Minimum soft till thickness & Last lateral shear stress \\
Maximum soft till thickness & Mean lateral shear stress \\
Mean soft till thickness & Maximum basal lateral stress \\
SD of soft till thickness & Cumulative lateral shear stress \\
Minimum MSGL height & Last ice flux \\
Mean MSGL height & Maximum ice flux \\
SD of MSGL height & Mean ice flux \\
Maximum of MSGL height & Cumulative ice flux \\
Minimum MSGL spacing & Last ice thickness \\
Mean MSGL spacing & Ice stream width \\
SD of MSGL spacing & Sum of last 10 'model years' ice velocity \\
Maximum of MSGL spacing & Mean of last 'model years' ice velocity \\
Median of MSGL spacing & Sum of last 100 'model years' of ice velocity \\
& Mean of last 100 'model years' of ice velocity \\
& Sum of last 1000 'model years' of ice velocity \\
& Mean of last 1000 'model years' of ice velocity
\end{tabular}

The parameters were extracted for each $1 \mathrm{~km}$ window along the area of interest. We note that, because the model retreats more slowly than the retreat chronology (Fig. 1) suggests, the timescales shown in relation to calculating velocities through time are likely to be longer than in reality. Data on timescale of velocity measurements should therefore be interpreted relatively rather than as absolute. 'Last' parameters, as indicated by their nomenclature, are from either the last time slice of the model output, or are calculated over the last 10, 100, or 1000 years of model time.

These data were then appended to the nearest DCP and statistics were calculated. On some acoustic profiles, a subbottom reflector was not observed either because there was no soft till or because its thickness exceeded the penetration depth of the acoustic signal (for example, across groundingzone wedges). In these cases, the data points were treated as 'no-data'.

\subsection{Numerical modelling}

We used a previously published flowline model of the ice stream to simulate ice stream retreat for the Marguerite Bay palaeo-ice stream (Jamieson and others, 2012; Jamieson and others, 2014). It is important to note that the morphology of MSGLs was not used to constrain the model apart from in aiding delineation of the width of the ice stream. As outlined

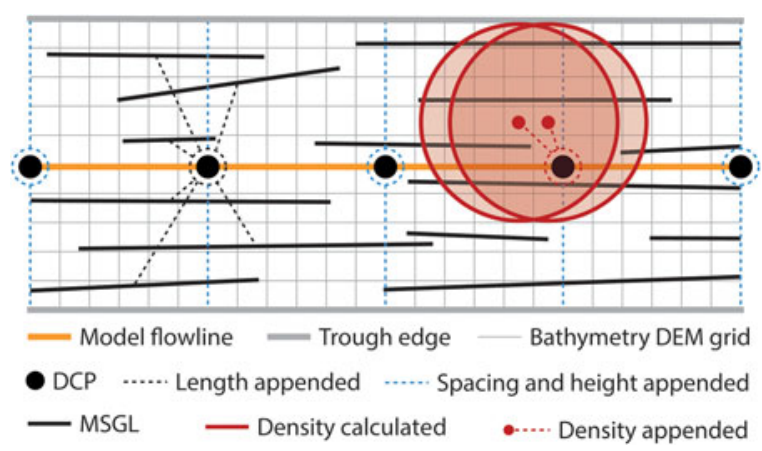

Fig. 2. Schematic representation of calculation of data in a 2-D space and its transformation onto a 1-D spatial analysis framework where it is recorded at data collection points (DCPs) situated on the model flowline. by Jamieson and others $(2012,2014)$ basal conditions in the model were defined using shear strength values measured on soft till recovered in cores (Ó Cofaigh and others, 2005; Ó Cofaigh and others, 2007; Kilfeather and others, 2011) and there was no numerical link between MSGLs and the basal stress or ice flow conditions of the model. A total of 160 simulations were carried out in order to test retreat response under different climatic and oceanic forcing combinations because the precise set of drivers behind the retreat is not fully known (Jamieson and others, 2014). We discarded models that did not retreat fully. From the 45 remaining model experiments which exhibit full retreat we note that although the precise timing of ice margin retreat varies, the overall retreat pattern does not significantly change despite the variance in forcing mechanisms. The 45 model runs simulating full ice stream retreat along the trough (Jamieson and others, 2014) were averaged and 24 glaciological parameters were then extracted (Table 1). The averaging of multiple model outputs avoids the pitfalls of relying on a single model simulation as a reflection of reality. The spatial resolution of the resulting model dataset is $1 \mathrm{~km}$, and is spaced identically to the grid upon which the geomorphological data have been measured.

\subsection{Data/model comparison}

To our knowledge, comparisons between measured MSGL characteristics and numerically-modelled ice flow conditions are still in their infancy (Fowler, 2010). Thus, in this preliminary analysis, we attempt to identify simple correlations between measured landform characteristics and modelled glaciological parameters. This is done by fitting linear, power law, log and exponential regressions on each possible 

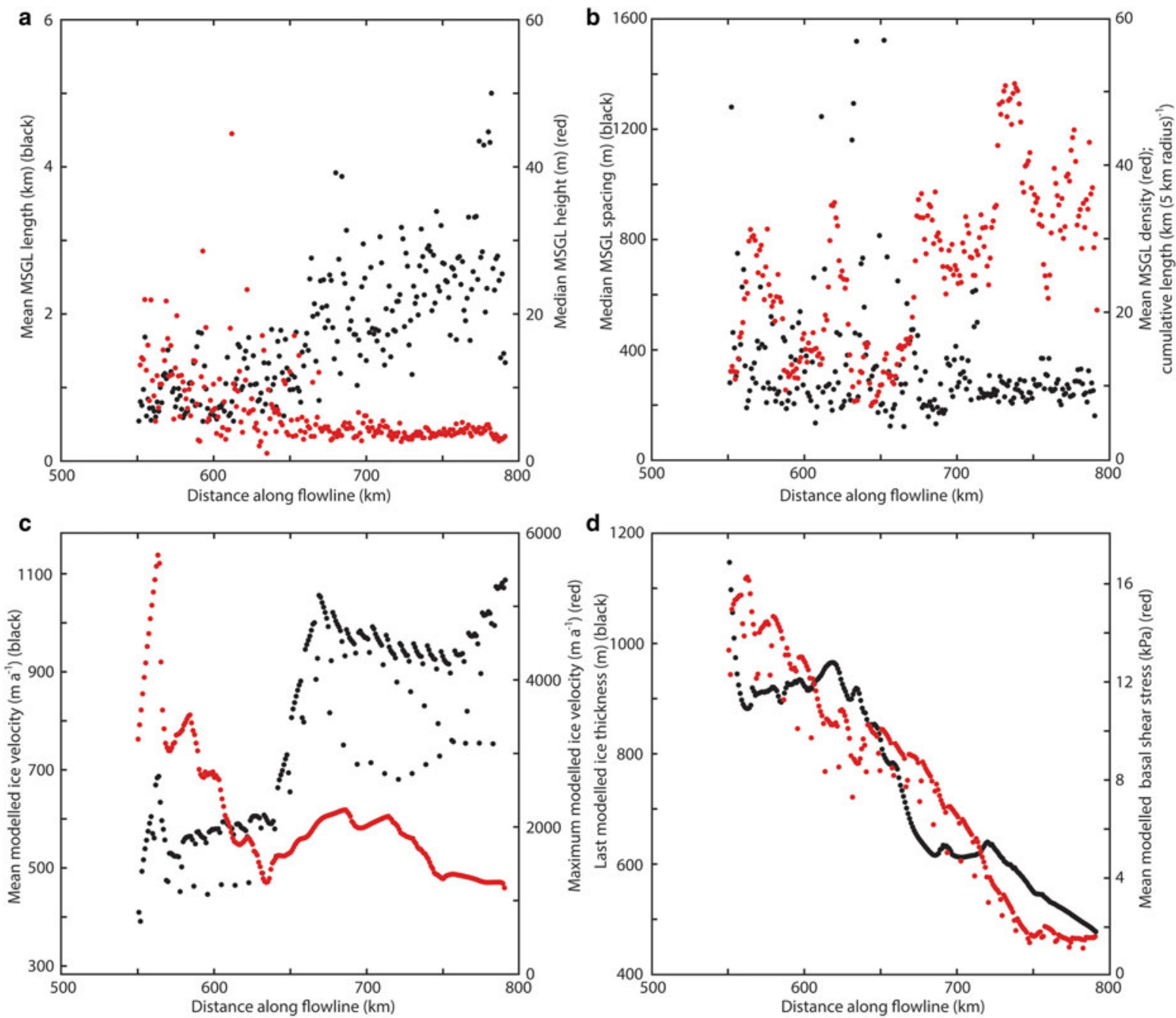

Fig. 3. Example MSGL statistics and modelled ice flow characteristics along Marguerite Trough where the continental shelf edge is at $\sim 800$ $\mathrm{km}$ from the ice divide. (a) The mean lineation length (black) increases towards the outer trough and that median MSGL height (red) can be higher towards the inner trough but is consistently low towards the outer trough. (b) The median MSGL spacing (black) can also be higher in the inner trough and that mean MSGL densities (red) generally increase towards the outer trough but can range widely around this trend. (c) The mean ice velocities (black) increase towards the outer shelf although are subject to local variation and that maximum ice velocities (red) increase towards the inner trough. (d) The last ice thickness (black) increases inland as expected, as do mean basal shear stresses (red), partly in relation to the mean ice thickness.

measured/modelled pair. In addition, we compare soft till thickness from the landform dataset against the other parameters in the measured dataset in order to identify whether landform geometry or distribution is related to soft till distribution. A total of 2400 regressions were therefore carried out. We identified the best form (linear, power, log or exponential) of relationship generated for each measured-modelled pair as that having the highest $r^{2}$ value. For all of the relationships with $r^{2}>0.5$, the associated $p$-values approach zero, indicating that the correlations are unlikely to have been delivered by chance.

\section{RESULTS}

\subsection{Measured and modelled distributions and patterns}

Figure 3a shows that long MSGLs tend to occur towards the shelf edge, but that short MSGLs can be found throughout the trough. Conversely, median MSGL heights are consistently low on the outer shelf but can be higher on the middle to inner shelf. Figure $3 \mathrm{~b}$ indicates that the median spacing of MSGLs follows a similar pattern to median MSGL height in that the MSGLs are more closely spaced on the outer shelf and are more variably spaced, often with wider gaps between them, on the mid- to inner-shelf. Figure $3 \mathrm{~b}$ also shows that the mean density of MSGLs varies significantly, but follows an increasing trend towards the outer portion of the trough.

As an indication of the averaged model output, Figure 3c shows that the mean ice velocity increases towards the outer trough, but that maximum ice velocities increase towards the inner trough. Figure $3 \mathrm{~d}$ indicates that the ice thickness at the grounding line immediately prior to deglaciation also increases inland as does mean basal shear stress.

\subsection{Glaciological processes and their correlations with MSGL morphology}

The $r^{2}$ values for the best form of correlation (e.g. linear, power, exponential or log) between each data/model pair are shown in Table 2 and regression equations are shown 


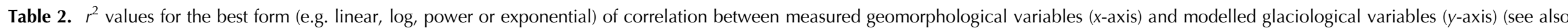
Table 1)

\begin{tabular}{|c|c|c|c|c|c|c|c|c|c|c|c|c|c|c|c|c|c|c|c|c|c|c|}
\hline & 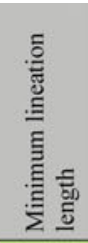 & 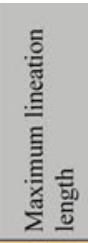 & 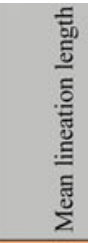 & 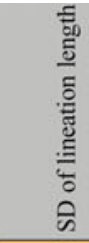 & 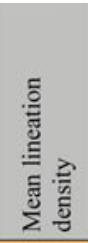 & 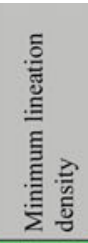 & 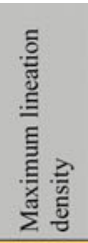 & 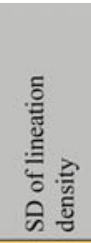 & 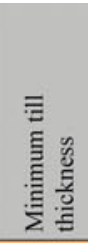 & 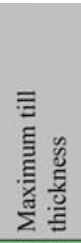 & 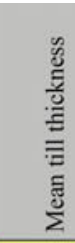 & 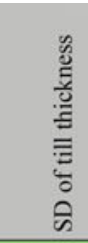 & 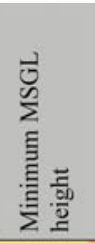 & 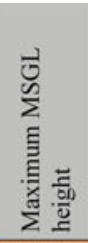 & 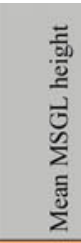 & 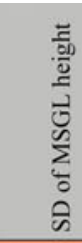 & 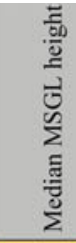 & 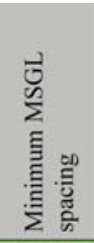 & 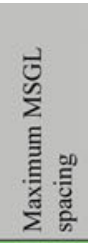 & 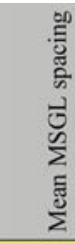 & 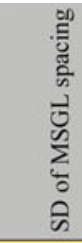 & 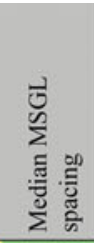 \\
\hline Trough width & 0.06 & 0.29 & 0.37 & 0.29 & 0.31 & 0.01 & 0.24 & 0.24 & 0.33 & 0.02 & 0.09 & 0.04 & 0.11 & 0.36 & 0.38 & 0.46 & 0.20 & 0.05 & 0.02 & 0.10 & 0.12 & 0.03 \\
\hline Last ice thickness & 0.22 & 0.42 & 0.65 & 0.42 & 0.46 & 0.09 & 0.48 & 0.41 & 0.22 & 0.19 & 0.01 & 0.16 & 0.15 & 0.33 & 0.51 & 0.47 & 0.41 & 0.09 & 0.00 & 0.12 & 0.06 & 0.09 \\
\hline Last basal shear stress & 0.18 & 0.10 & 0.26 & 0.13 & 0.06 & 0.00 & 0.04 & 0.07 & 0.10 & 0.01 & 0.03 & 0.00 & 0.00 & 0.31 & 0.26 & 0.32 & 0.16 & 0.01 & 0.01 & 0.00 & 0.00 & 0.00 \\
\hline Maximum basal shear stress & 0.17 & 0.44 & 0.63 & 0.44 & 0.49 & 0.10 & 0.42 & 0.33 & 0.34 & 0.16 & 0.03 & 0.17 & 0.16 & 0.41 & 0.58 & 0.55 & 0.42 & 0.08 & 0.01 & 0.12 & 0.09 & 0.07 \\
\hline Cumulative basal shear stress & 0.19 & 0.43 & 0.64 & 0.43 & 0.48 & 0.09 & 0.41 & 0.34 & 0.33 & 0.18 & 0.04 & 0.18 & 0.16 & 0.41 & 0.60 & 0.55 & 0.44 & 0.08 & 0.01 & 0.12 & 0.09 & 0.07 \\
\hline Mean basal shear stress & 0.18 & 0.41 & 0.60 & 0.40 & 0.44 & 0.07 & 0.37 & 0.32 & 0.32 & 0.13 & 0.05 & 0.13 & 0.13 & 0.41 & 0.55 & 0.54 & 0.40 & 0.07 & 0.01 & 0.10 & 0.08 & 0.05 \\
\hline Last lateral shear stress & 0.19 & 0.36 & 0.57 & 0.37 & 0.36 & 0.04 & 0.33 & 0.31 & 0.28 & 0.10 & 0.04 & 0.10 & 0.11 & 0.47 & 0.57 & 0.58 & 0.38 & 0.06 & 0.01 & 0.08 & 0.07 & 0.04 \\
\hline Maximum lateral shear stress & 0.14 & 0.40 & 0.55 & 0.39 & 0.42 & 0.06 & 0.37 & 0.32 & 0.35 & 0.10 & 0.05 & 0.12 & 0.15 & 0.44 & 0.56 & 0.56 & 0.37 & 0.07 & 0.01 & 0.12 & 0.11 & 0.05 \\
\hline Cumulative lateral shear stress & 0.14 & 0.42 & 0.59 & 0.42 & 0.46 & 0.08 & 0.41 & 0.34 & 0.36 & 0.14 & 0.04 & 0.17 & 0.17 & 0.42 & 0.58 & 0.56 & 0.39 & 0.08 & 0.01 & 0.13 & 0.11 & 0.06 \\
\hline Mean lateral shear stress & 0.12 & 0.36 & 0.50 & 0.35 & 0.40 & 0.04 & 0.33 & 0.30 & 0.34 & 0.08 & 0.06 & 0.09 & 0.12 & 0.42 & 0.50 & 0.53 & 0.32 & 0.06 & 0.01 & 0.10 & 0.10 & 0.03 \\
\hline Last ice flux & 0.29 & 0.17 & 0.44 & 0.21 & 0.14 & 0.01 & 0.14 & 0.17 & 0.06 & 0.09 & 0.01 & 0.04 & 0.02 & 0.34 & 0.39 & 0.39 & 0.29 & 0.02 & 0.01 & 0.00 & 0.00 & 0.01 \\
\hline Maximum ice flux & 0.26 & 0.28 & 0.54 & 0.30 & 0.20 & 0.02 & 0.21 & 0.19 & 0.15 & 0.06 & 0.01 & 0.04 & 0.08 & 0.45 & 0.54 & 0.52 & 0.41 & 0.04 & 0.00 & 0.05 & 0.03 & 0.05 \\
\hline Cumulative ice flux & 0.05 & 0.44 & 0.47 & 0.40 & 0.60 & 0.14 & 0.54 & 0.40 & 0.35 & 0.15 & 0.01 & 0.21 & 0.21 & 0.24 & 0.40 & 0.38 & 0.27 & 0.11 & 0.01 & 0.19 & 0.13 & 0.10 \\
\hline Mean ice flux & 0.09 & 0.03 & 0.10 & 0.05 & 0.00 & 0.00 & 0.01 & 0.01 & 0.00 & 0.01 & 0.02 & 0.00 & 0.02 & 0.10 & 0.13 & 0.09 & 0.12 & 0.01 & 0.00 & 0.01 & 0.00 & 0.04 \\
\hline Last velocity & 0.16 & 0.09 & 0.22 & 0.12 & 0.04 & 0.01 & 0.03 & 0.06 & 0.10 & 0.01 & 0.04 & 0.01 & 0.00 & 0.34 & 0.27 & 0.34 & 0.16 & 0.01 & 0.00 & 0.00 & 0.00 & 0.01 \\
\hline Maximum velocity & 0.18 & 0.16 & 0.33 & 0.18 & 0.08 & 0.00 & 0.07 & 0.08 & 0.13 & 0.01 & 0.06 & 0.01 & 0.04 & 0.43 & 0.40 & 0.45 & 0.27 & 0.01 & 0.01 & 0.02 & 0.02 & 0.01 \\
\hline Mean ice velocity & 0.27 & 0.29 & 0.55 & 0.32 & 0.26 & 0.09 & 0.31 & 0.25 & 0.04 & 0.18 & 0.07 & 0.12 & 0.11 & 0.24 & 0.43 & 0.33 & 0.40 & 0.06 & 0.00 & 0.07 & 0.01 & 0.11 \\
\hline Cumulative ice velocity & 0.13 & 0.02 & 0.01 & 0.01 & 0.06 & 0.01 & 0.02 & 0.01 & 0.28 & 0.00 & 0.12 & 0.03 & 0.04 & 0.01 & 0.01 & 0.01 & 0.02 & 0.01 & 0.05 & 0.05 & 0.12 & 0.00 \\
\hline Sum of last 10 years ice & 0.03 & 0.09 & 0.10 & 0.09 & 0.04 & 0.01 & 0.01 & 0.01 & 0.14 & 0.06 & 0.12 & 0.04 & 0.01 & 0.24 & 0.17 & 0.23 & 0.09 & 0.01 & 0.02 & 0.00 & 0.02 & 0.00 \\
\hline Mean of last 10 years ice velocity & 0.03 & 0.09 & 0.10 & 0.09 & 0.04 & 0.01 & 0.01 & 0.01 & 0.14 & 0.06 & 0.12 & 0.04 & 0.01 & 0.24 & 0.17 & 0.23 & 0.09 & 0.01 & 0.02 & 0.00 & 0.02 & 0.00 \\
\hline Sum of last 100 years ice velocity & 0.01 & 0.19 & 0.14 & 0.16 & 0.18 & 0.03 & 0.11 & 0.06 & 0.30 & 0.01 & 0.13 & 0.01 & 0.10 & 0.15 & 0.16 & 0.18 & 0.08 & 0.03 & 0.01 & 0.05 & 0.08 & 0.01 \\
\hline Mean of last 100 years ice velocity & 0.01 & 0.19 & 0.14 & 0.16 & 0.18 & 0.03 & 0.11 & 0.06 & 0.30 & 0.01 & 0.13 & 0.01 & 0.10 & 0.15 & 0.16 & 0.18 & 0.08 & 0.03 & 0.01 & 0.05 & 0.08 & 0.01 \\
\hline Sum of last $1 \mathrm{ka}$ ice velocity & 0.10 & 0.47 & 0.55 & 0.44 & 0.55 & 0.11 & 0.50 & 0.37 & 0.37 & 0.13 & 0.02 & 0.17 & 0.21 & 0.32 & 0.50 & 0.47 & 0.34 & 0.10 & 0.01 & 0.16 & 0.12 & 0.08 \\
\hline Mean of last $1 \mathrm{ka}$ ice velocity & 0.10 & 0.47 & 0.55 & 0.44 & 0.55 & 0.11 & 0.50 & 0.37 & 0.37 & 0.13 & 0.02 & 0.17 & 0.21 & 0.32 & 0.50 & 0.47 & 0.34 & 0.10 & 0.01 & 0.16 & 0.12 & 0.08 \\
\hline Minimum till thickness & 0.00 & 0.19 & 0.12 & 0.15 & 0.22 & 0.02 & 0.25 & 0.19 & $\mathrm{n} / \mathrm{a}$ & $\mathrm{n} / \mathrm{a}$ & $\mathrm{n} / \mathrm{a}$ & $\mathrm{n} / \mathrm{a}$ & 0.09 & 0.11 & 0.18 & 0.16 & 0.08 & 0.04 & 0.03 & 0.13 & 0.14 & 0.03 \\
\hline Maximum till thickness & 0.03 & 0.02 & 0.05 & 0.02 & 0.05 & 0.07 & 0.10 & 0.02 & $\mathrm{n} / \mathrm{a}$ & $\mathrm{n} / \mathrm{a}$ & $\mathrm{n} / \mathrm{a}$ & $\mathrm{n} / \mathrm{a}$ & 0.05 & 0.05 & 0.07 & 0.05 & 0.05 & 0.02 & 0.00 & 0.01 & 0.00 & 0.01 \\
\hline Mean till thickness & 0.03 & 0.04 & 0.02 & 0.03 & 0.02 & 0.01 & 0.01 & 0.04 & $\mathrm{n} / \mathrm{a}$ & $\mathrm{n} / \mathrm{a}$ & $\mathrm{n} / \mathrm{a}$ & $\mathrm{n} / \mathrm{a}$ & 0.00 & 0.02 & 0.01 & 0.04 & 0.00 & 0.02 & 0.01 & 0.05 & 0.06 & 0.01 \\
\hline SD of till thickness & 0.01 & 0.06 & 0.06 & 0.05 & 0.11 & 0.03 & 0.25 & 0.13 & $\mathrm{n} / \mathrm{a}$ & $\mathrm{n} / \mathrm{a}$ & $\mathrm{n} / \mathrm{a}$ & $\mathrm{n} / \mathrm{a}$ & 0.10 & 0.04 & 0.09 & 0.05 & 0.06 & 0.05 & 0.00 & 0.03 & 0.02 & 0.01 \\
\hline
\end{tabular}

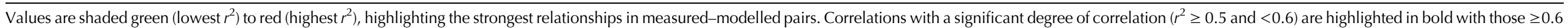
also being highlighted in italics. 
in Supplementary Table S1. In total, we identify 39 statistically significant $(p<0.05)$ correlations where $r^{2} \geq 0.5$ and which may therefore demonstrate glaciological controls upon MSGL geometry that are unlikely to have resulted by chance. Four of these relationships, all of which relate mean lineation length to measures of basal shear stress or ice thickness have $r^{2}$ values above 0.6 . For measured/modelled pairs where no significant correlation is found, we assume that the specific attributes of the analysed MSGLs are not strongly dependent upon the glaciological context. For the measured/modelled pairs that show a reasonably strong and significant degree of correlation, here defined as $r^{2} \geq 0.5$ and $p<0.05$, we now describe their relationships in detail.

\subsection{Lineation length}

The distribution of MSGLs in Marguerite Trough follows a pattern of general elongation both towards the continental shelf edge (Figs 1 and 3a) and towards the centre of the trough (Livingstone and others, this issue). However, short MSGLs are ubiquitous along the trough. Measurements of mean lineation length show a nonlinear (exponential) negative relationship to basal shear stress parameters (Fig. 4). Table 2 indicates that, in particular, maximum, cumulative and mean basal shear stresses are correlated with mean lineation length $\left(r^{2}=0.63,0.64\right.$ and 0.6 , respectively). Where shear stress is high, MSGLs are generally short and their mean lengths only vary between 0.5 and $1.5-2 \mathrm{~km}$. However, under low shear stress, MSGLs tend to be long and their mean lengths span a much wider range (from 1 to $5 \mathrm{~km})$. This is reflected in the increase in SD of lineation length when basal shear stress parameters are low, and the low SDs under high maximum, cumulative or mean shear stresses (Fig. 4b). Notably, the relationship between mean MSGL length and basal shear stress modelled for the last time-slice of ice coverage, which describes the imprint of the ice stream immediately before the grounding line retreated past the DCP, is much weaker (Table 2) than for the longer-term (mean/cumulative) basal shear stress conditions.

Maximum, minimum, mean and the SD of lateral shear stress are also correlated with mean MSGL length (Table 2) in a similar pattern and strength to the basal shear stress relationships.

The ice thickness modelled immediately prior to retreat and mean MSGL length are exponentially, inversely correlated (Fig. 5a; $r^{2}=0.65$ ) such that MSGLs are on average at their longest under thin ice and the range of mean MSGL lengths decreases under thicker ice. For example, under $900 \mathrm{~m}$ of ice, MSGLs are between 0.5 and $1.8 \mathrm{~km}$ long, but under $500 \mathrm{~m}$ of ice, mean lineation lengths range between 1.2 and $5 \mathrm{~km}$.

Our results also show that mean MSGL lengths are higher under higher mean ice velocity conditions $\left(r^{2}=0.55\right.$; Fig. 5b). However, if ice discharge is considered as a volume rather than a velocity, longer mean MSGL lengths correlate with reduced ice flux conditions $\left(r^{2}=0.54\right.$; Fig. 5c).

\subsection{MSGL Density}

Mean MSGL density, measured by cumulative length per $5 \mathrm{~km}$ search radius, is inversely correlated with cumulative (i.e. long-term) ice flux $\left(r^{2}=0.6\right.$; Fig. $\left.6 a\right)$ and, to a lesser extent, the mean and sum of the final 1 ka of ice velocity $\left(r^{2}=0.55\right.$ : Table 2). As cumulative ice flux increases the range of maximum MSGL densities increases, but the mean MSGL density decreases (Fig. 6a). The bottom left parameter space of the maximum MSGL density vs cumulative ice flux scatter-plots do not contain data suggesting, where cumulative ice flux is low, maximum MSGL density is likely to be high, whereas if cumulative ice fluxes are high, there is significantly more variability in maximum MSGL density. This variability is not seen when cumulative ice flux is plotted against mean MSGL density, in that densities tend to have a near constant range of $\sim 20 \mathrm{~km}$ per $5 \mathrm{~km}$ search radius throughout the parameter space. Furthermore, we find meaningful, negative relationships between mean ice velocity over the final 1 ka of flow and the maximum and mean density of MSGLs (Fig. 6b). These patterns of relationships are similar to those between maximum and mean MSGL density and cumulative ice flux, but $r^{2}$ is slightly weaker (Table 2).

\subsection{MSGL Height}

The heights of MSGLs show strong, positive relationships with modelled basal shear stress and ice thickness characteristics (Fig. 7). The mean and SD of MSGL height is exponentially correlated with maximum basal shear stress (Figs 7a and b), as well as with mean and cumulative basal shear stress and with lateral shear stress (Table 2). Larger means and SDs in MSGL heights are possible with the presence of increased mean, maximum or cumulative basal shear stress conditions. The last ice thickness is also correlated with the mean MSGL height (Fig. 7c), such that the mean lineation height is very limited under a thin $(<600 \mathrm{~m}$ thick) final stage of ice coverage, but if the thickness of ice immediately prior to deglaciation is thick, then the mean MSGL height can be highly variable. Whatever the basal shear stress or ice thickness conditions, it is always possible to have very low MSGLS.

The SD of MSGL height is weakly correlated with the width of the ice stream trough (Fig. 8a). For example, once the trough becomes wider than $\sim 32 \mathrm{~km}$, the SD of heights of the MSGLs are limited to below $5 \mathrm{~m}$, but below $32 \mathrm{~km}$ in width, SDs of MSGL height range up to $50 \mathrm{~m}$. The mean MSGL height also correlates with the maximum ice flux $\left(r^{2}=0.54\right.$; Fig. $\left.8 \mathrm{~b}\right)$ and the sum and mean of the last $1 \mathrm{ka}$ of ice velocity (both have $r^{2}=0.5$; Table 2 ).

\subsection{Summary of key results}

Very few of the correlations between the measured MSGL characteristics and modelled ice dynamical properties show strong and significant correlations (Table 2), but there are some notable exceptions, which we summarise here:

The length of lineations is inversely correlated with basal shear stress and ice flux. Long MSGLs form only where modelled basal shear stress values and maximum ice fluxes are low.

Long-term mean ice velocity is positively correlated with MSGL length. The relationship is particularly strong for long MSGLs, which can only be found where mean ice velocity is high over a long time period, while short MSGLs form under any mean ice velocity or maximum ice flux 

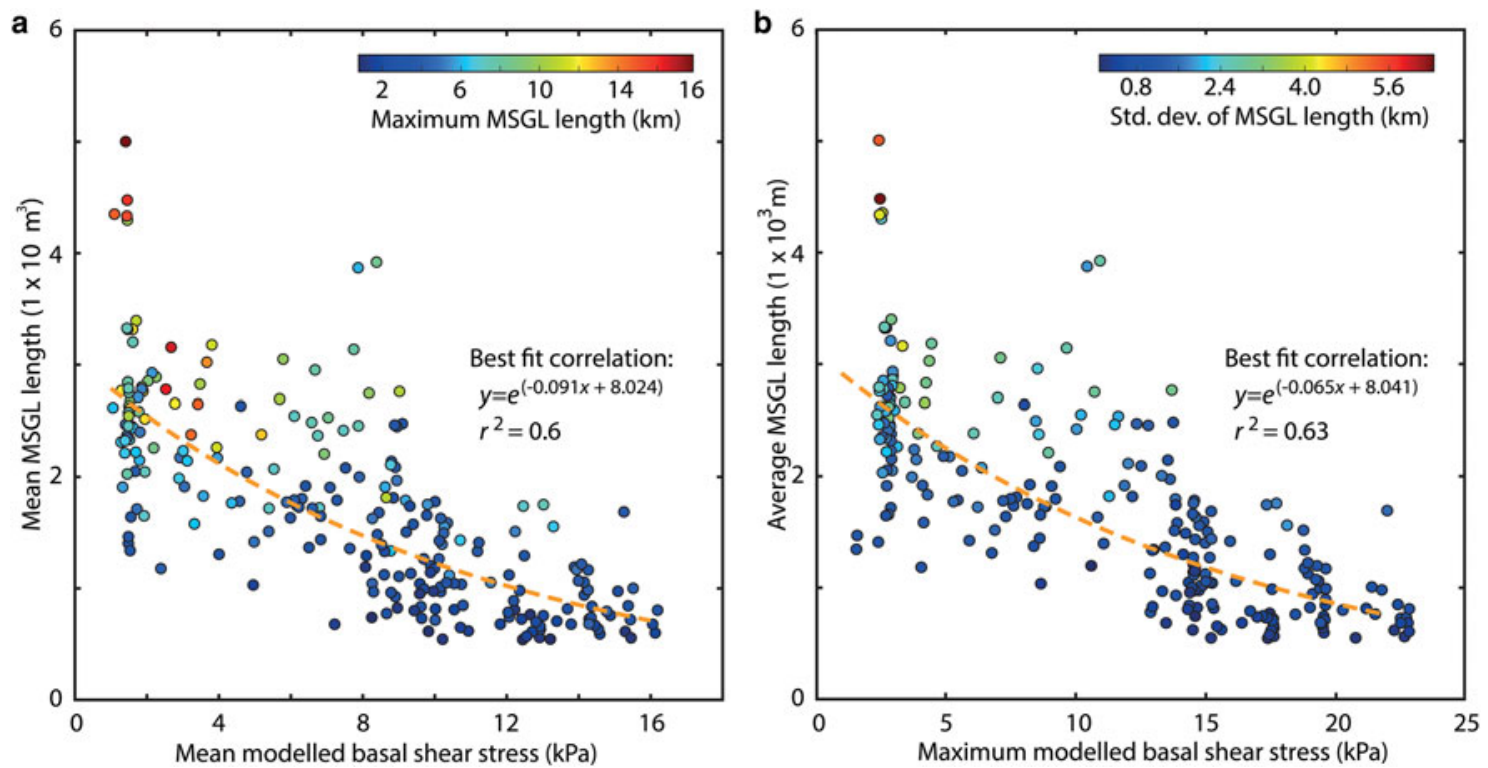

Fig. 4. Basal shear stress parameters and their correlations to mean MSGL length. The best fit correlations are identified by the orange dashed line and its equation and $r^{2}$ value are also shown. (a) Mean basal shear stress. (b) Maximum basal shear stress.
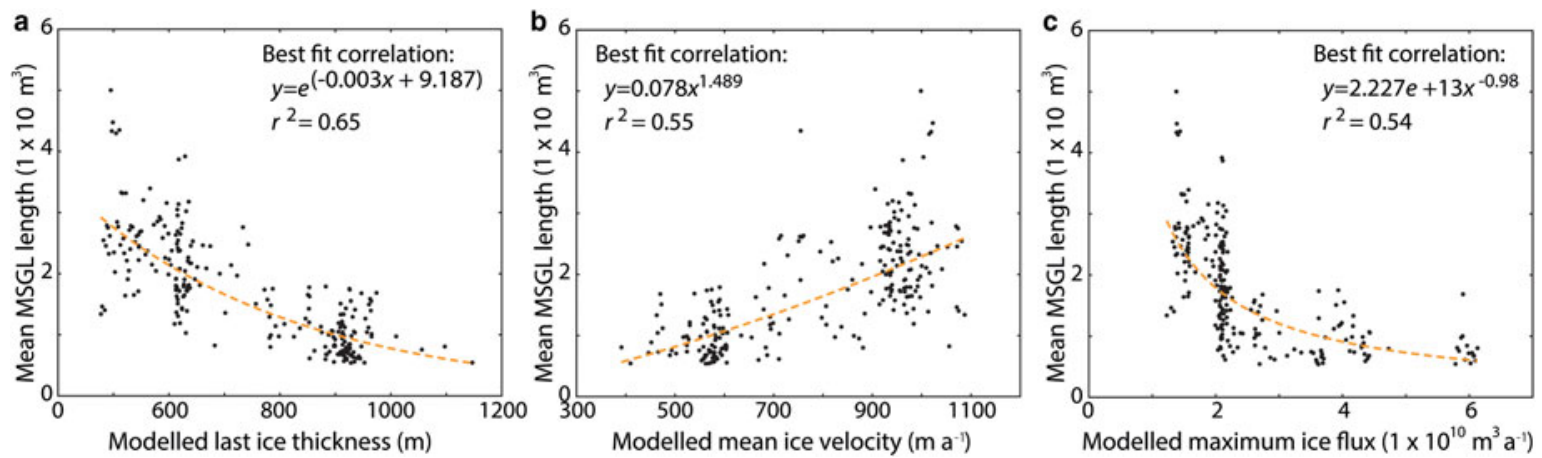

Fig. 5. The correlations of mean MSGL length to various modelled ice flow parameters. The best fit correlations are identified by the orange dashed line and its equation and $r^{2}$ value are also shown. (a) Last ice thickness vs mean MSGL length. (b) Mean ice velocity vs mean MSGL length. (c) Maximum ice flux vs mean MSGL length.
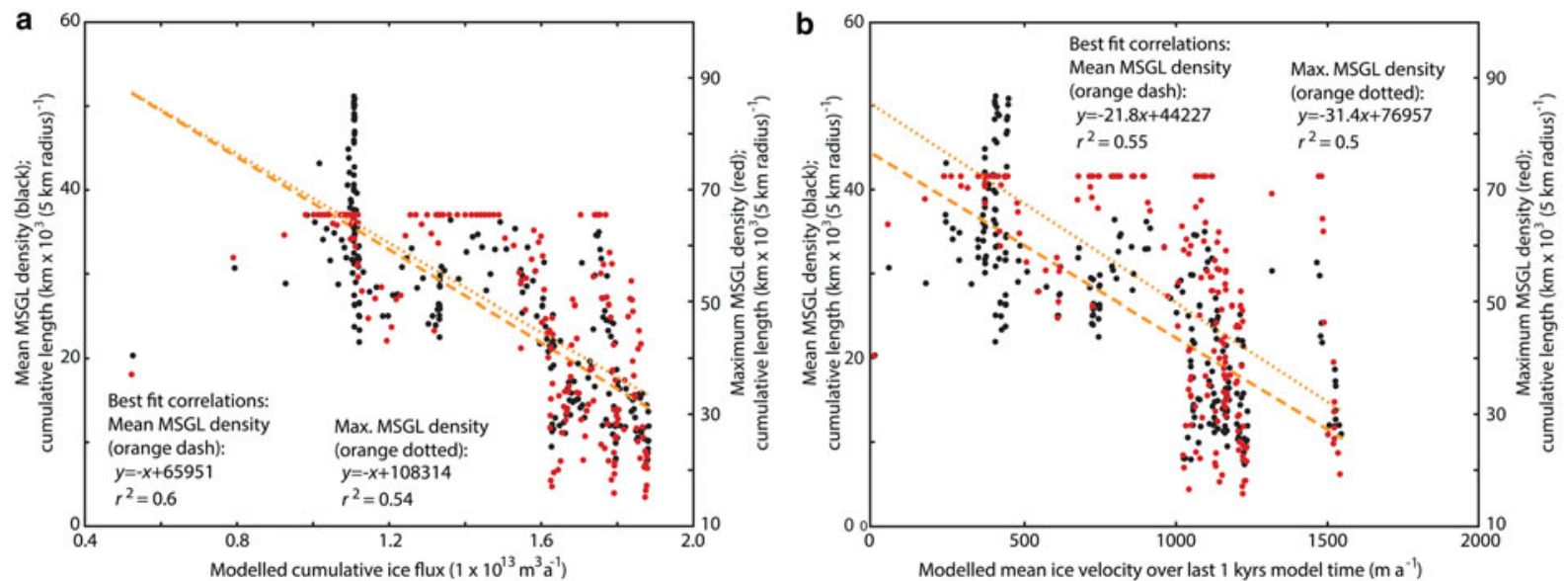

Fig. 6. MSGL density in relation to ice discharge parameters. The best fit correlations are identified by the orange dashed line and its equation and $r^{2}$ value are also shown. (a) Mean MSGL density (black) and maximum MSGL density (red) vs cumulative modelled ice flux. (b) Mean MSGL density (black) and maximum MSGL density (red) vs mean modelled ice velocity over the final 1 ka of model time. Note in (a), the greater variability in maximum MSGL density when cumulative ice fluxes are at their greatest and that the range (max value - min value for any given ice flux) of the mean MSGL density appears to remain relatively similar despite changing cumulative ice flux. Similar relationships are identified in (b) between mean or maximum MSGL density and the mean of the last 1 ka of ice velocities. 

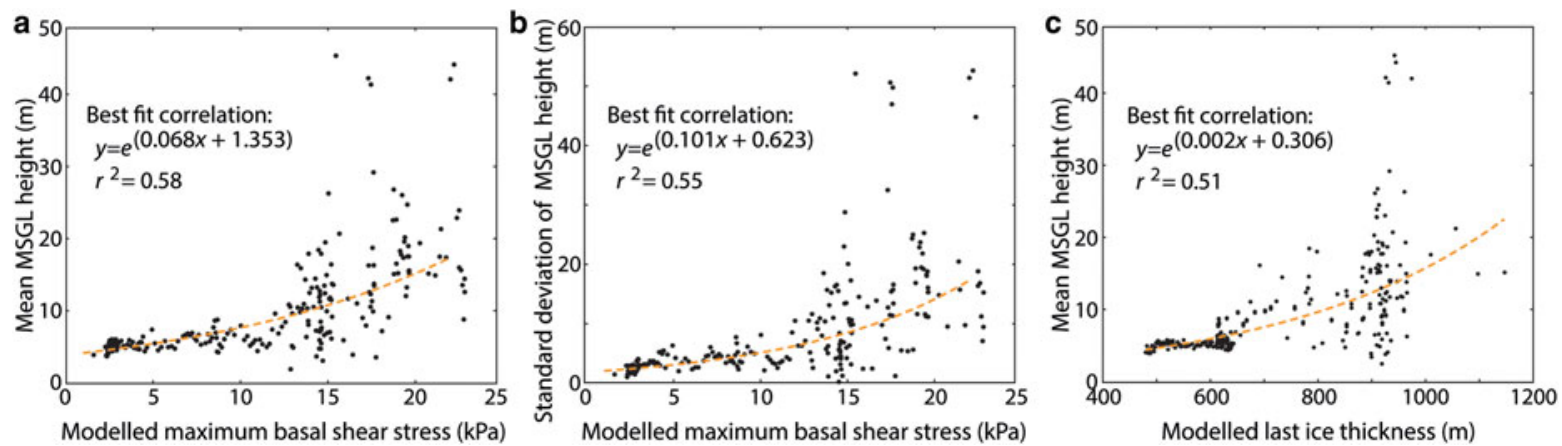

Fig. 7. Mean MSGL heights and their relationships to ice flow parameters. The best fit correlations are identified by the orange dashed line and its equation and $r^{2}$ value are also shown. (a) Mean MSGL height vs maximum basal shear stress. (b) SD of MSGL height vs maximum basal shear stress. (c) Last ice thickness vs Mean MSGL height.

conditions. However, in the final stages prior to grounding line retreat from a particular location, longer MSGLs appear to be related to lower maximum ice flux conditions.

Lineation density is negatively correlated with cumulative ice flux conditions. Maximum lineation density tends to be high in areas that have experienced low cumulative ice flux, but can be significantly more variable where cumulative ice flux is increased.

The mean height of lineations increases when basal shear stress is high and when mean ice flux is also high. High MSGLs are also found where their density is low and where they are short. MSGLs are lower, more abundant (higher density) and more attenuated when basal shear stress is low.

The SD of MSGL heights is largest when the trough width is narrower, but when the trough widens to more than 30-35 km, MSGL heights are more uniform, varying by only $4-5 \mathrm{~m}$.

Our analysis indicates that the spacing of MSGLs cannot be linked to any of the modelled glaciological parameters. Soft till thickness also seems to bear no relation to the model or to the characteristics of the landforms developed in it.

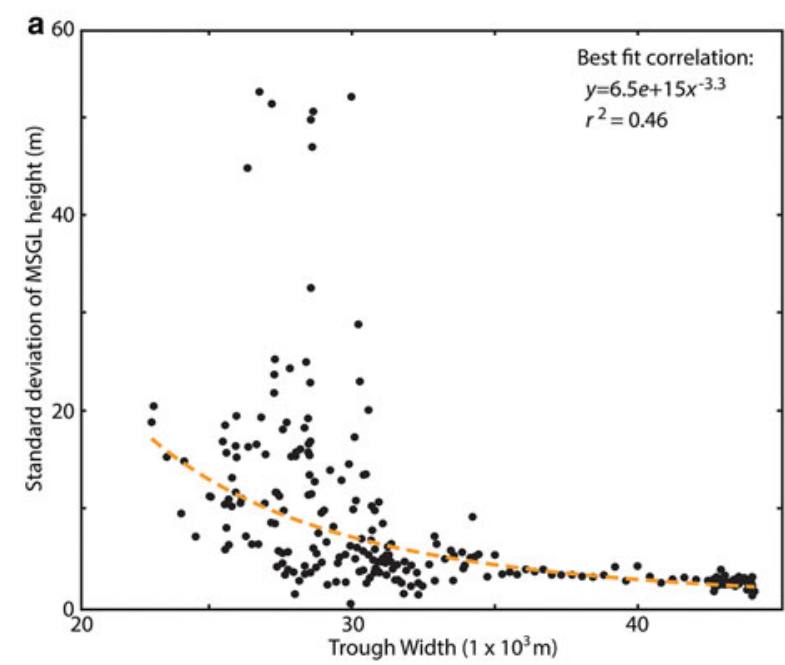

\section{DISCUSSION}

We will now consider some key questions relating to MSGL formation, including whether MSGL length is controlled by ice velocity, whether basal shear stress plays a crucial role in MSGL development and over what timescales MSGLs might evolve. Some of our correlations are useful in that they rule out particular relationships between MSGL formation and ice flow, and these will be discussed prior to an assessment of the limitations and uncertainties of our analysis.

\subsection{Is MSGL length controlled by ice velocity?}

It has been suggested that lineation elongation is a function of ice flow velocity (Clark, 1993; Stokes and Clark, 2002; Briner, 2007). Our results confirm that as basal shear stress decreases and ice velocity increases, lineations are longer. Indeed, Figure 9 suggests that most ice discharge-related parameters have some form of relationship to shear stress and to lineation length. However, high velocities cannot be disentangled from low basal shear stresses in terms of the ultimate physical cause (Fig. 9d). This is because modelled basal shear stress is a function of an applied basal slip condition, in this case constrained by shear strength data on soft till (Ó Cofaigh and others, 2007; Kilfeather and others, 2011),

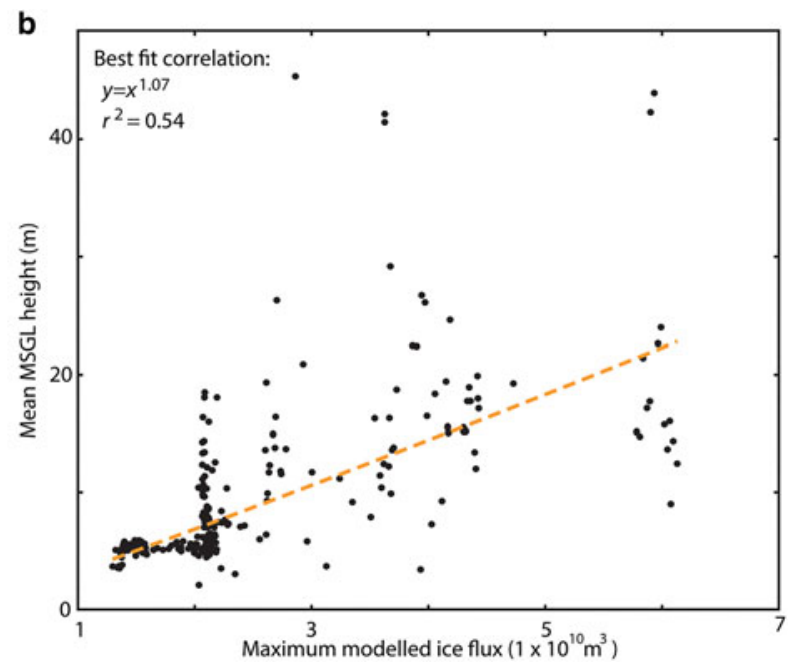

Fig. 8. MSGL height parameters correlated against width, velocity and thickness factors. The best fit correlations are identified by the orange dashed line and its equation and $r^{2}$ value are also shown. (a) Trough width vs the SD of MSGL height. Note the correlation is weaker than other correlations shown, but it is the strongest where the influence of width is concerned. (b) Maximum ice flux vs mean MSGL height. 

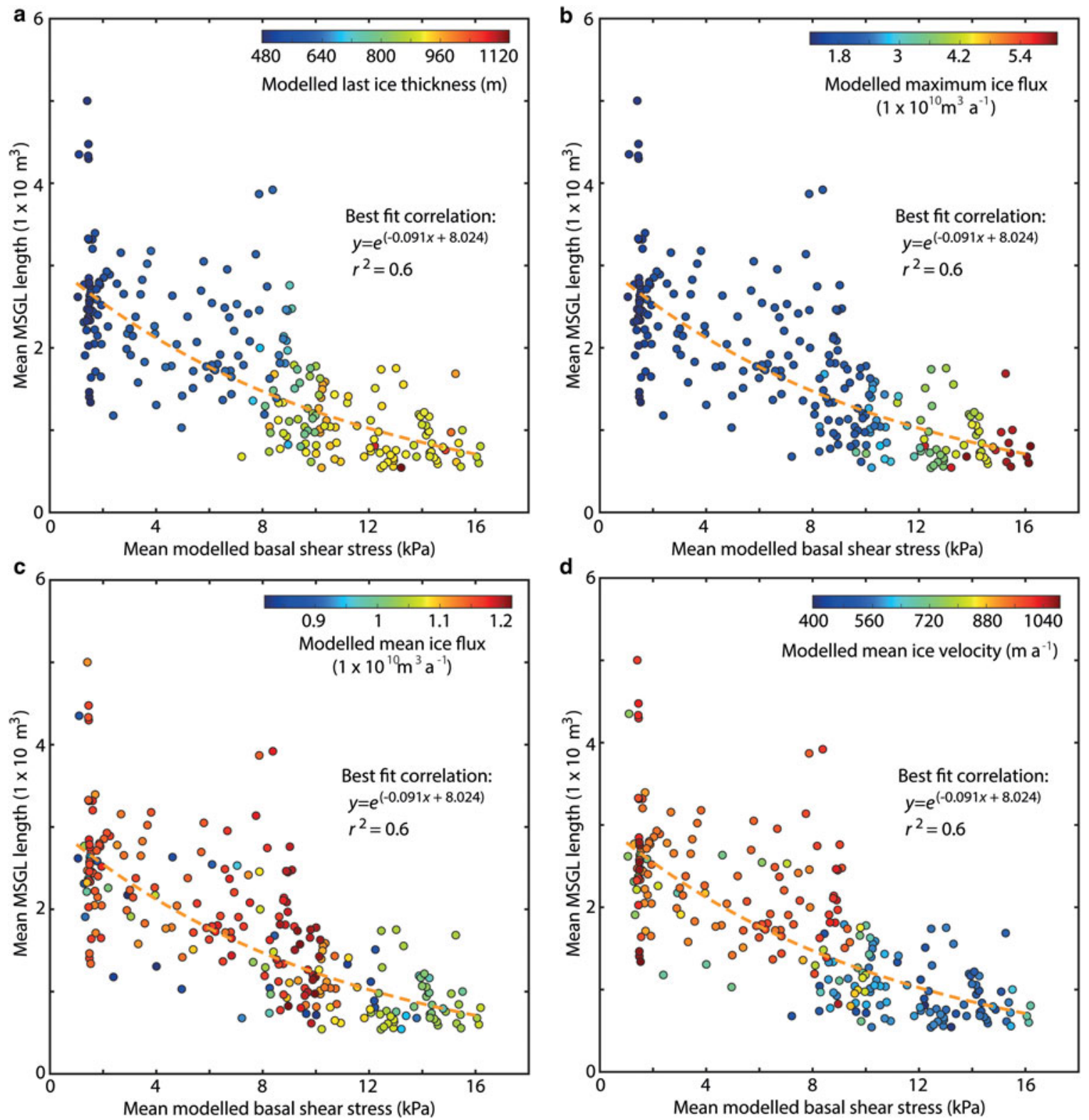

Fig. 9. Ice discharge properties compared against mean basal shear stress and mean lineation length. The best fit correlations are identified by the orange dashed line and its equation and $r^{2}$ value are also shown. (a) and (b) show that last ice thickness and maximum ice flux have the most clear-cut co-relationship with mean basal shear stress and mean lineation length. (c) and (d) show a less tidy relationship, with low mean ice velocity or low mean ice flux outliers appearing throughout the mean basal shear stress vs mean lineation length scatter.

and evolving ice velocity and effective pressure. Low modelled shear stress occurs where the bed is weak, but it increases with enhanced effective pressure (Jamieson and others, 2012; Jamieson and others, 2014). Although these are all interrelated, our results show that the strongest correlation is with basal shear stress, possibly indicating that this is the most important parameter. We therefore initially discuss MSGL morphology in relation to basal shear stress.

Short MSGLs are found in all areas of the ice stream bed where there is soft sediment, but there is a trend for longer MSGLs to be present towards the shelf edge and towards the centre of the trough (Figs. 1 and 3; Livingstone and others, 2013; Livingstone and others, 2016). This explains why minimum MSGL length does not correlate with any modelled glaciological parameters, which all evolve along the trough (Table 2). Thus, our analysis suggests that: (i) short MSGLs can develop under the full spectrum of basal conditions simulated in this case; and (ii) their formation is not limited by any of the processes operating at the bed of the ice stream, apart from the requirement for deformable sediment to be present. This also implies that new, short MSGLs could be formed at any time in the life of an ice stream. On the other hand, longer MSGLs appear to form only where basal shear stress or mean ice flux are low and where mean ice velocity is high.

Unfortunately, a limited number of available shear strength measurements from soft till in cores from the outer and middle parts of Marguerite Trough (Ó Cofaigh and others, 2007; Kilfeather and others, 2011) do not enable a relationship between lineation geometry and till strength to be confirmed. However, MSGLs have been noted to form only in the upper soft till layer (Dowdeswell and others, 2004; Ó Cofaigh and others, 2005, 2007), and not at the surface of underlying stiff till either in Marguerite Trough (Ó Cofaigh and others, 2005), or in other Antarctic palaeo-ice stream troughs (Ó Cofaigh and others, 2007). Thus, the correlation between lineation length and basal shear stress and ice velocity suggests that maximum MSGL length is limited by the speed of the overlying ice and the basal conditions. This is consistent 
with a more detailed spatial analysis of lineation length vs soft till thickness, which also indicates that long lineations cannot form in thin, soft till (Livingstone and others, 2016). The implication is that if MSGLs are found in thick, soft till, then their lengths may have the potential to be used as a quantitative indicator of past ice velocity.

\subsection{Relationships between basal shear stresses and MSGL characteristics}

The mean and SD of MSGL heights all increase exponentially when basal shear stress conditions increase. The range (SD) of MSGL heights under low shear stress is always small, and in Marguerite Trough, their mean height is always above 2-3 m (Fig. 7a) and their distribution or morphology appears unaffected by the convergence or divergence of ice flow as controlled by trough width (Table 2). Furthermore, the SD of the height of MSGL appears to be limited to below $\sim 5-6 \mathrm{~m}$ until a threshold of $\sim 12 \mathrm{kPa}$ in maximum basal shear stress is reached (Fig. 7b), whereupon they can range by up to $50 \mathrm{~m}$ in height and grow to a maximum of $17.8 \mathrm{~km}$ long (Livingstone and others, 2016). Therefore, we suggest that these contrasts between lineation heights in low vs high basal shear stress zones may reflect the importance of effective pressure at the bed for the movement of soft till and therefore for the process of MSGL formation.

In relation to previous theories of MSGL formation, we find that two predictions made by the groove-ploughing theory for MSGLs (Clark and others, 2003) are not met in our analysis or in that of Livingstone and others (2016). First, despite the fact that trough narrowing controlled grounding line retreat rates (Jamieson and others, 2012), the prediction that transverse spacing of grooves should change in proportion to the convergence of ice flow, is not met because we see no relationship between MSGL spacing in relation to the narrowing of Marguerite Bay palaeo-ice stream. Second, the prediction that the higher till shear strength should produce lower MSGLs is in contrast to our finding that high basal shear stresses are likely to generate high, rather than low, MSGLs.

Whatever the model for MSGL formation, we suggest that basal stress conditions can influence MSGL elongation. Because long MSGLs occur under low shear stress/fast ice flow conditions, it is tempting to assume that where MSGLs reach an elongated state it may be a consequence of rapid erosion and transport of sediment from the MSGL bodies, and/or from the inter-MSGL depressions and subsequent sediment accumulation at the MSGL tail. Conversely, under high basal shear stress/low velocity conditions MSGLs would be created less quickly as the more consolidated till provides more resistance to ice flow and thus erosion. Under such a model, it is likely that the higher consolidation of till might enable an MSGL to exist for longer, while adjacent sediment was slowly getting removed, thus generating relatively higher MSGLs compared with under low stress conditions.

\subsection{Is MSGL morphology and distribution a record of final ice flow, or of long-term average glacial conditions?}

Given present understanding, it is unclear how much time is required for MSGL formation. It is hypothesised that bedforms can elongate over decades to hundreds of years (Clark, 1993). Recent data from beneath the modern Rutford Ice Stream confirm that some elongate bedforms are formed and eroded over years to decades (Smith and others, 2007; Smith and Murray, 2009).

Our data show that mean lineation lengths increase nonlinearly with mean ice velocity, but decrease in relation to the highest maximum ice flux (i.e. greatest over potentially short periods) (Figs $5 \mathrm{~b}$ and c). The oddity that maximum ice fluxes appear inversely related in comparison with longterm mean ice velocity (Fig. 3c) is due to the fact that, in our ice stream model, the highest ice velocities occur for only a very short period of time in inland regions during rapid deglaciation of the trough when ice was warmer. Furthermore, due to a bed slope that deepens inland, ice fluxes at the grounding line are strongly conditioned to increase as retreat progresses (Thomas, 1979; Schoof, 2007). Thus, maximum fluxes are effectively distributed in a reverse pattern compared with mean ice velocities. Therefore, if maximum ice flux (which is closely linked to maximum ice velocity) caused long MSGLs to form very rapidly (years), then it might be expected that the longest MSGLs would be observed in the inner shelf parts of the trough. This is clearly not the case. Nevertheless, the correspondence to longer-term mean ice velocity conditions suggests that the length of MSGLs is related to the period of time over which they formed and that although elongation might begin immediately, the length of an MSGL cannot instantaneously synchronise with the overlying velocity of the ice. The implication of this is that, although MSGLs may form at any period during the lifecycle of an ice stream, they require time to 'mature' in order to become significantly elongated. The maturation period could be as short as a decade because our mapping tells us that MSGLs are found on the back of grounding zone wedges, which grew on such a timescale (Bart and Owolana, 2012; Livingstone and others, 2016) and our correlations include these MSGLs in their comparison with ice velocity.

The implication of this time vs velocity mode of elongation is that long MSGLs must form more quickly under high mean ice velocities and under weak bed conditions. This is consistent with conditions where erosion and/or soft till supply are likely to be consistently high. This means that, on average, a $10 \mathrm{~km}$ long MSGL on the middle shelf may have been forming for longer than a $10 \mathrm{~km}$ long MSGL on the outer shelf. Furthermore, if MSGLs can be neighbours within a region of similar ice conditions, but can be 'born' at different times, elongated MSGLs are likely to have been forming for longer than the neighbouring, shorter MSGLs.

MSGL elongation as a product of ice flow velocity and duration of MSGL formation is consistent with the fact that the majority of long lineations are found on the middle and outer shelf sections of palaeo-ice stream troughs, where soft till is deposited and one would also expect to find both the fastest sustained ice flow (i.e. high mean velocities) and the lowest basal shear stress conditions at the Last Glacial Maximum (Wellner and others, 2001; Ó Cofaigh and others, 2002; Ó Cofaigh and others, 2005; Livingstone and others, 2013). Furthermore, this time-dependent mean velocity model allows for outer shelf regions to be interspersed with shorter, younger MSGLs as in Marguerite Trough, and for enhanced preservation potential on the middle vs the outer shelf, whereby more consolidated till and lower 
mean ice stream velocities result in less erosion of MSGL bodies.

This velocity-duration model is also supported by the comparison between mean lineation density and cumulative ice flux (Fig. 6a), which suggests that although lineations can form under most ice flux conditions, they are increasingly dense under lower cumulative ice flux situations, and under such conditions are more likely to show a narrow range of maximum densities. Time may therefore be an important factor controlling not only the elongation, but the density of lineations: new MSGLs are constantly formed in response to evolving basal conditions but existing lineations can either continue evolving, or may be eroded or reworked. Thus, the age of MSGLs, or at least the age of their initial formation within a particular area, is likely to be highly variable. These findings are consistent with those presented in the accompanying paper (Livingstone and others, 2016), where it is suggested that MSGL characteristics are indicative of a continually evolving bed, which has then immediately been preserved upon deglaciation.

In Marguerite Trough, MSGLs are mapped on the surface of grounding zone wedges that are thought to form during periods of grounding line stability or minor readvance. Although the timescales over which GZWs could develop are uncertain, the chronology in Marguerite Trough (Fig. 1) implies that formation was on the order of decades to centuries rather than millennia (see Livingstone and others, 2016 and references therein). This may provide a more accurate understanding of the rapidity of MSGL elongation in comparison with the timing that is calculated by the model because, as we have previously noted, the modelled ice stream consistently retreats too slowly. Thus, we suggest that any velocity-duration model must allow for rapid rates of elongation, for example, those observed for bedform formation and erosion beneath the Rutford Ice Stream (Smith and others, 2007; Smith and Murray, 2009), as well as for slower rates in systems where chronologies suggest longer periods of unchanging ice flow and grounding line conditions. This would require the elongation rate to be controlled by additional parameters. For example, the rate of sediment delivery may control soft till thickness and thus MSGL length. Conversely, erosion could result in reduced accumulations or the complete absence of soft till, such as in the inner shelf of Marguerite Bay, which would inhibit MSGL formation and elongation (e.g. Livingstone and others, 2016), and/or hydrology.

\subsection{What do non-correlations tell us about MSGL formation?}

Parameters that show no relationship may also be informative for our understanding of how MSGL morphology and distribution are controlled. For example, we find there is no discernible link between MSGL spacing and the glaciological characteristics of the modelled ice stream (Table 2). This may indicate that the spacing of MSGLs is controlled by conditions other than those extracted from our model, or that they may be randomly controlled or that spacing may be related to localised perturbations at the ice/bed interface, perhaps related to bedrock bumps, hydrology, or stiffening or weakening of till (Clark and others, 2003). We find no link between soft till thickness and the spacing of MSGLs, and no indication that spacing is related to overall trough width. Assuming this finding is not a function of the 1-D transformation of till thickness data in our analysis, it suggests that regional sediment supply and large-scale topographic factors are unimportant for controlling MSGL spacing.

There appears to be no significant correlation between measures of till thickness and any glaciological or geomorphological parameters. If this lack of correlation is not influenced by areas where no basal reflector could be identified (which would erroneously result in a soft till thickness of zero), it suggests that in Marguerite Trough the availability of sediment was always sufficient to enable MSGL growth and continued evolution except where bedrock crops out, such as in parts of the inner shelf of Marguerite Bay (Ó Cofaigh and others, 2005; Livingstone and others, 2016).

\subsection{Limitations and uncertainties}

This study is one of the first attempts to quantify the relationships between measured statistics of MSGL morphometry and modelled aspects of ice stream flow. However, the relationships identified here need to be tested on other ice stream and ice sheet beds to understand whether the findings are more widely applicable. Ideally, exposed MSGLs would be compared against the output of high-resolution 3-D numerical models of ice stream flow that incorporate full calculations of stress over a full glacial cycle (i.e. growth and decay). This might allow us to identify whether similar glaciological variables lead to similar patterns of lineation morphology under different ice streams or, more generally, whether statistical descriptions of MSGL flow-sets can be related to glaciological variables (Hillier and others, 2013). The prospect for testing these relationships against conditions at modern ice stream beds in Antarctica (King and others, 2009; Smith and Murray, 2009) and Greenland (Jezek and others, 2011) offers further potential for refining our understanding of the processes of formation of MSGLs and other elongated bedforms.

We have been unable to test for the potential importance of subglacial hydrology in MSGL evolution because the model contains no treatment of meltwater and its influence on ice flow. Subglacial meltwater is crucial for controlling the deformability of the sediment and is an important control in the transport of sediment, either in distributed or discrete drainage systems (Swift and others, 2002; Cook and Swift, 2012; Cowton and others, 2012). Furthermore, meltwater is a key component of the rilling instability theory of MSGL formation (Fowler, 2010; Fowler and Chapwanya, 2014) in which the distribution of a water film controls sediment transport and the spacing and elongation of landforms through the formation of rills at the ice/bed interface. Thus, the inclusion of a hydrological and till transport component within the model would aid consideration of questions relating to the rilling instability, evolving rates of basal sliding and sediment transport and their impact upon MSGL morphology.

The importance of bedrock control on MSGL distribution and form has not been tested here, and we have not made any distinction between MSGLs that formed in soft till vs those that might partly be seeded by underlying bedrock. However, on the inner- and mid-shelf, seismic data indicate that the sedimentary bedrock and crystalline basement lie at shallow depths beneath the bed surface (Bart and Anderson, 1995; Larter and others, 1997; Anderson, 1999). It is therefore likely that some of the MSGLs may be bedrock controlled (Ó Cofaigh and others, 2002; Graham and others, 
2009; Livingstone and others, 2016, this issue), and we acknowledge that a component of their height, length or density may be influenced by the morphology of any underlying bedrock bumps. Indeed, the spacing of MSGLs, which is more variable on the inner and mid-shelf, could be a reflection of such a control. Nevertheless, we predict that the correlation between high modelled basal shear stresses and MSGL height would likely become more significant, if a bedrock substrate were accounted for in our model. This is because the bedrock would provide greater resistance than the soft till, thus causing higher shear stresses to be simulated on the inner and mid-shelf where the higher MSGLs tend to be found (Fig. 3). It is also likely that the correlation between MSGL length and basal shear stress, whereby longer MSGLs can be found under lower shear stress conditions, would become stronger because on the inner and mid-shelf the MSGLs tend to be shorter and the basal shear stresses are already at their highest in the model.

\section{CONCLUSIONS}

The formation of MSGLs has been linked to fast-flowing ice streams both in the past, and at present. The glaciological controls upon the evolving morphology of these lineated sedimentary features have remained elusive, but their elongation has been hypothesised to be a function of ice flow speed (Hart, 1999; Stokes and Clark, 2002; Briner, 2007). We compared a comprehensive dataset of geometric measurements of over 5000 MSGLs in Marguerite Trough on the Antarctic Peninsula (described in Paper 1; Livingstone and others, 2016, this issue), against glaciological output from a suite of numerical model runs that simulate the retreat of the ice stream. Our exploratory analysis leads us to a number of conclusions:

The elongation of MSGLs appears related to both the basal shear stress and, to a slightly lesser extent, to the speed of the ice flow, the two parameters being linked to each other in the model. Thus, our results quantitatively confirm the idea that longer MSGLs are related to faster ice flow.

Snapshots of glaciological conditions, especially ice velocity, immediately prior to deglaciation have very little correlation with MSGL morphology. Furthermore, given that short MSGLs can form under most modelled shear stress conditions, but long MSGLs can only form once the shear stress is lower, we suggest that longer, more 'mature' MSGLs develop over timescales of decades to centuries in the case of the Marguerite Bay palaeo-ice stream.

The height of MSGLs is also linked to basal shear stress conditions. We suggest that low ice flow velocities in areas of high shear stress are unable to erode high MSGLs into lower-profile, more streamlined features, or that high MSGLs create high basal shear stresses.

Many of the morphological characteristics of MSGLs show little correlation with the dynamics of the overlying ice as simulated for the Marguerite Bay palaeo-ice stream. For example, short-term ice velocity and soft till thickness have little influence over MSGL length or height, and we cannot find any glaciological control upon the spacing of MSGLs, their minimum spacing or soft till thickness as compared against our numerical model.
The analysis carried out here is based on a single ice stream. A broader suite of numerical simulations of ice stream flow over full glacial cycles should be tested against measurements of lineation distribution and morphology in both terrestrial and marine settings in order to build a clearer picture of the glaciological controls upon MSGL evolution.

By making the first attempt at quantifying the relationships between the morphology of MSGLs and the glaciological characteristics of a modelled ice stream, we anticipate that in the future, it will be possible to use MSGL measurements on former ice stream beds to quantitatively reconstruct the behaviour of past ice streams. Such a quantitative link would provide a new form of constraint for palaeo-ice sheet models, reducing the uncertainty in simulations of past, rapid and large-scale ice stream retreat.

\section{SUPPLEMENTARY MATERIAL}

To view supplementary material for this article, please visit http://dx.doi.org/10.1017/jog.2016.19

\section{ACKNOWLEDGEMENTS}

This work was funded by Natural Environmental Research Council (NERC) UK standard grants NE/G015430/1 and NE/G018677/1. Jamieson was supported by NERC Fellowship NE/J018333/1 and Spagnolo was supported by NERC new investigator grant NE/J004766/1. This research would not have been possible without the hard work of scientists and crew during research cruises JR59, JR71, JR157 and NBP0201. We thank Chris Clark for useful discussions and two anonymous reviewers for comments that helped to improve the manuscript. Data produced in this manuscript are available from the corresponding author.

\section{REFERENCES}

Alley RB, Blankenship DD, Bentley CR and Rooney ST (1986) Deformation of till beneath ice stream B, West Antarctica. Nature, 322(6074), 57-59

Anderson JB (1999) Antarctic Marine Geology. Cambridge University Press, Cambridge

Anderson JB and Fretwell LO (2008) Geomorphology of the onset area of a paleo-ice stream, Marguerite Bay, Antarctic Peninsula. Earth Surf. Process. Landf., 33(4), 503-512 (doi: 10.1002/esp.1662)

Bart PJ and Anderson JB (1995) Seismic record of glacial events affecting the pacific margin of the Northwestern Antarctic Peninsula. In Cooper AK, Barker PF and Brancolini G eds. Geology and Seismic Stratigraphy of the Antarctic Margin. American Geophysical Union, Antarctic Research Series, Washington D.C., 75-95

Bart PJ and Owolana B (2012) On the duration of West Antarctic Ice Sheet grounding events in Ross Sea during the Quaternary. Quat. Sci. Rev., 47, 101-115 (doi: 10.1016/j.quascirev.2012.04.023)

Boulton GS (1987) A theory of drumlin formation by subglacial sediment deformation. In Menzies J and Rose J eds. Drumlin Symposium. Manchester, 1985, A.A. Balkema, Rotterdam, 25-80

Briner JP (2007) Supporting evidence from the New York drumlin field that elongate subglacial bedforms indicate fast ice flow. Boreas, 36(2), 143-147 (doi: 10.1111/j.1502-3885.2007. tb01188.x)

Clark CD (1993) Mega-scale glacial lineations and cross-cutting iceflow landforms. Earth Surf. Process. Landf., 18(1), 1-29 (doi: 10.1002/esp.3290180102) 
Clark CD, Tulaczyk SM, Stokes CR and Canals M (2003) A grooveploughing theory for the production of mega-scale glacial lineations, and implications for ice-stream mechanics. J. Glaciol., 49 (165), 240-256

Cook SJ and Swift DA (2012) Subglacial basins: Their origin and importance in glacial systems and landscapes. Earth-Sci. Rev., 115 (4), 332-372 (doi: 10.1016/j.earscirev.2012.09.009)

Cowton T, Nienow P, Bartholomew I, Sole A and Mair D (2012) Rapid erosion beneath the Greenland ice sheet. Geology, $\mathbf{4 0}$ (4), 343-346 (doi: 10.1130/g32687.1)

Dowdeswell JA, Ó Cofaigh C and Pudsey CJ (2004) Thickness and extent of the subglacial till layer beneath an Antarctic palaeoice stream. Geology, 32(1), 13-16

Engelhardt H and Kamb B (1997) Basal hydraulic system of a West Antarctic ice stream: constraints from borehole observations. J. Glaciol., 43, 207-230

Engelhardt H, Humphrey N, Kamb B and Fahnestock M (1990) Physical conditions at the base of a fast moving Antarctic ice stream. Science, 248, 57-59

Fowler AC (2010) The formation of subglacial streams and megascale glacial lineations. Proc. R. Soc. A: Math., Phys. Eng. Sci., 466(2123), 3181-3201 (doi: 10.1098/rspa.2010.0009)

Fowler AC and Chapwanya M (2014) An instability theory for the formation of ribbed moraine, drumlins and mega-scale glacial lineations. Proc. R. Soc. A: Math., Phys. Eng. Sci., 470(2171) (doi: 10.1098/rspa.2014.0185)

Graham AGC and 5 others (2009) Bedform signature of a West Antarctic palaeo-ice stream reveals a multi-temporal record of flow and substrate control. Quat. Sci. Rev., 28(25-26), 27742793 (doi: 10.1016/j.quascirev.2009.07.003)

Harden SL, DeMaster DJ and Nittrouer CA (1992) Developing sediment geochronologies for high-latitude continental shelf deposits: a radiochemical approach. Mar. Geol., 103(1-3), 69-97 (doi: 10.1016/0025-3227(92)90009-7)

Hart JK (1999) Identifying fast ice flow from landform assemblages in the geological record: a discussion. Ann. Glaciol., 28(1), 59-66 (doi: 10.3189/172756499781821887)

Heroy DC and Anderson JB (2007) Radiocarbon constraints on Antarctic Peninsula ice sheet retreat following the last glacial maximum (LGM). Quat. Sci. Rev., 26(25-28), 3286-3297

Hillier JK, Smith MJ, Clark CD, Stokes CR and Spagnolo M (2013) Subglacial bedforms reveal an exponential size-frequency distribution. Geomorphol., 190, 82-91 (doi: 10.1016/j.geomorph. 2013.02.017)

Jamieson SSR and 5 others (2014) Understanding controls on rapid ice-stream retreat during the last deglaciation of Marguerite Bay, Antarctica, using a numerical model. J. Geophys. Res.: Earth Surf., 119(2), 247-263 2013JF002934 (doi: 10.1002/ 2013JF002934)

Jamieson SSR and 6 others (2012) Ice-stream stability on a reverse bed slope. Nat. Geosci., 5(11), 799-802

Jezek K and 6 others (2011) Radar images of the bed of the Greenland Ice Sheet. Geophys. Res. Lett., 38(1), L01501 (doi: 10.1029/2010GL045519)

Kilfeather AA and 5 others (2011) Ice-stream retreat and ice-shelf history in Marguerite Trough, Antarctic Peninsula: sedimentological and foraminiferal signatures. Geol. Soc. Am. Bull., 123(5-6), 997-1015 (doi: 10.1130/b30282.1)

King EC, Hindmarsh RCA and Stokes CR (2009) Formation of megascale glacial lineations observed beneath a West Antarctic ice stream. Nat. Geosci., 2(8), 585-588 (doi: Doi 10.1038/ Ngeo581)

Larter RD, Rebesco M, Vanneste LE, GambôA LAP and Barker PF (1997) Cenozoic Tectonic, Sedimentary and Glacial History of the Continental Shelf West Of Graham Land, Antarctic Peninsula. In Barker PF and Cooper AK eds. Geology and Seismic Stratigraphy of the Antarctic Margin. 2. American Geophysical Union, Antarctic Research Series, 1-27

Larter RD and 8 others (2009) Subglacial bedforms reveal complex basal regime in a zone of paleo-ice stream convergence,
Amundsen Sea embayment, West Antarctica. Geology, 37(5), 411-414 (doi: 10.1130/g25505a.1)

Livingstone SJ and 5 others (2013) Glacial Geomorphology of Marguerite Bay palaeo-ice stream, western Antarctic Peninsula. J. Maps, 9(4), 558-572 (doi: 10.1080/17445647.2013.829411 and 10.1080/17445647.2013.829411-SUP0001)

Livingstone SJ and 7 others (2016) subglacial processes on an Antarctic ice stream bed 1: sediment transport and bedform genesis inferred from marine geophysical data. J. Glaciol.

Ó Cofaigh C, Pudsey CJ, Dowdeswell JA and Morris P (2002) Evolution of subglacial bedforms along a paleo-ice stream, Antarctic Peninsula continental shelf. Geophys. Res. Lett., 29 (8), 1199 (doi: 10.1029/2001gl014488)

Ó Cofaigh C and 6 others (2005) Flow dynamics and till genesis associated with a marine-based Antarctic palaeo-ice stream. Quat. Sci. Rev., 24(5-6), 709-740

Ó Cofaigh C, Evans J, Dowdeswell JA and Larter RD (2007) Till characteristics, genesis and transport beneath Antarctic paleo-ice streams. J. Geophys. Res., 112(F3), F03006 (doi: 10.1029/ 2006jf000606)

Ó Cofaigh C, Stokes CR, Lian OB, Clark CD and Tulacyzk S (2013) Formation of mega-scale glacial lineations on the Dubawnt Lake Ice Stream bed: 2. sedimentology and stratigraphy. Quat. Sci. Rev., 77(0), 210-227 (doi: 10.1016/j. quascirev.2013.06.028)

Ottesen D, Dowdeswell JA and Rise L (2005) Submarine landforms and the reconstruction of fast-flowing ice streams within a large Quaternary ice sheet: The 2500-km-long Norwegian-Svalbard margin $\left(57^{\circ}-80^{\circ} \mathrm{N}\right)$. Geol. Soc. Am. Bull., 117(7-8), 1033-1050 (doi: 10.1130/b25577.1)

Pope PG and Anderson JB (1992) Late quaternary glacial history of the northern Antarctic Peninsula's western continental shelf: evidence from the marine record. Antarct. Res. Ser., 57, 63-91

Schoof C (2007) Ice sheet grounding line dynamics: Steady states, stability, and hysteresis. J. Geophys. Res., 112(F3), F03S28 (doi: 10.1029/2006jf000664)

Schoof CG and Clarke GKC (2008) A model for spiral flows in basal ice and the formation of subglacial flutes based on a ReinerRivlin rheology for glacial ice. J. Geophys. Res.: Solid Earth, 113(B5), B05204 (doi: 10.1029/2007JB004957)

Sejrup HP and 13 others (2003) Configuration, history and impact of the Norwegian Channel Ice Stream. Boreas, 32(1), 18-36 (doi: 10.1080/03009480310001029)

Smith AM and Murray T (2009) Bedform topography and basal conditions beneath a fast-flowing West Antarctic ice stream. Quat. Sci. Rev., 28(7-8), 584-596 (doi: 10.1016/j.quascirev. 2008.05.010)

Smith AM and 6 others (2007) Rapid erosion, drumlin formation, and changing hydrology beneath an Antarctic ice stream. Geology, 35(2), 127-130

Spagnolo M and 7 others (2014) Size, shape and spatial arrangement of mega-scale glacial lineations from a large and diverse dataset. Earth Surf. Process. Landf., 39(11), 1432-1448 (doi: 10.1002/ esp.3532)

Stoker M and Bradwell T (2005) The Minch palaeo-ice stream, NW sector of the British-Irish ice sheet. J. Geol. Soc., 162, $425-428$

Stokes CR and Clark CD (1999) Geomorphological criteria for identifying Pleistocene ice streams. Ann. Glaciol., 28(1), 67-74 (doi: 10.3189/172756499781821625)

Stokes CR and Clark CD (2002) Are long subglacial bedforms indicative of fast ice flow? Boreas, 31(3), 239-249 (doi: 10.1111/ j.1502-3885.2002.tb01070.x)

Stokes CR, Fowler AC, Clark CD, Hindmarsh RCA and Spagnolo M (2013a) The instability theory of drumlin formation and its explanation of their varied composition and internal structure. Quat. Sci. Rev., 62(0), 77-96 (doi: 10.1016/j.quascirev. 2012.11.011)

Stokes CR and 5 others (2013b) Formation of mega-scale glacial lineations on the Dubawnt Lake Ice Stream bed: 1. size, shape and 
spacing from a large remote sensing dataset. Quat. Sci. Rev., 77(0), 190-209 (doi: 10.1016/j.quascirev.2013.06.003)

Swift DA, Nienow PW, Spedding N and Hoey TB (2002) Geomorphic implications of subglacial drainage configuration: rates of basal sediment evacuation controlled by seasonal drainage system evolution. Sedimentary Geol., 149(1-3), 5-19 (doi: 10.1016/S0037-0738(01)00241-X)

Thomas RH (1979) The dynamics of marine ice sheets. J. Glaciol., 24 (90), 167-177
Tulaczyk SM, Scherer RP and Clark CD (2001) A ploughing model for the origin of weak tills beneath ice streams: a qualitative treatment. Quat. Int., 86(1), 59-70 (doi: 10.1016/S1040-6182(01) 00050-7)

Wellner JS, Lowe AL, Shipp SS and Anderson JB (2001) Distribution of glacial geomorphic features on the Antarctic continental shelf and correlation with substrate: implications for ice behavior. J. Glaciol., 47(158), 397-411 (doi: 10.3189/ 172756501781832043)

MS received 9 October 2015 and accepted in revised form 5 November 2015; first published online 14 March 2016 